\title{
PERAN PARTAI POLITIK LOKAL DALAM PENYELANGGARAAN OTONOMI KHUSUS DI PROVINSI ACEH
}

\author{
M. Fahrudin Andriyansyah \\ Pascasarjana Fakultas Hukum Universitas Brawijaya \\ J1. MT. Haryono No. 169, Ketawanggede, Kota Malang, Jawa Timur 65145. (0341)571260 \\ Email: fahrudin.dba@gmail.com
}

\begin{abstract}
The existence of political parties that are only national in nature with structures centered in the center often makes the party's orientation ignore local interests. The failure of political parties in the implementation of regional autonomy can be interpreted as necessary to regulate a new party system in Indonesia. One of them is by separating between national political parties and local political parties in the regions. The role of local political parties that have existed in Aceh in the implementation of special autonomy and at the same time see whether local political parties have played a role or not in the implementation of special autonomy in Aceh. Local political parties, especially the Aceh Party in 2014 obtained the highest number of seats in the Aceh People's Representative Council (DPRA) compared to national political parties, so the Aceh Party had a strategic position as the leader of the DPRA and the leadership of a number of DPRA equipment. The role of local political parties can be seen through the role of the faction of local political parties in the DPRA, especially the Aceh Party faction, which is related to the role of legislation, budgeting and Controling. The Aceh Party faction has played a role in organizing special autonomy in Aceh
\end{abstract}

Key words: Local Political Parties, Special Autonomy, The Aceh Party, Aceh People's Representative Council

\begin{abstract}
ABSTRAK
Keberadaan partai politik yang hanya bersifat nasional dengan struktur yang berpucuk di pusat kerap kali membuat orientasi partai mengabaikan kepentingan lokal. Tidak berjalannya partai politik dalam penyelengaraan otonomi daerah dapat dimaknai bahwa perlu untuk mengatur sistem kepartaian baru di Indonesia dengan melakukan pemisahan antara partai politik nasional dengan partai politik lokal yang ada di daerah. Kebijakan otonomi daerah maka harus dibarengi dengan adanya otonomi politik melalui partai politik lokal. Penelitian ini akan melihat peran partai politik lokal yang telah ada di Aceh dalam penyelenggaraan otonomi khusus sekaligus melihat apakah partai politik lokal telah berperan atau tidak di dalam penyelenggaraan otonomi khusus di Aceh. Partai politik lokal terutama Partai Aceh pada tahun 2014 memperoleh jumlah kursi terbanyak di Dewan Perwakilan Rakyat Aceh (DPRA) dibandingkan dengan partai politik nasional, sehingga Partai Aceh memiliki posisi strategis seperti peran legislasi, anggaran dan pengawasan. Fraksi Partai Aceh telah berperan dalam penyelenggaran otonomi khusus di Aceh.
\end{abstract}

Kata Kunci: Partai Politik Lokal, Otonomi Khusus, Partai Aceh, DPRA 


\section{PENDAHULUAN}

Permasalahan yang dihadapi Indonesia adalah tata kelola multi-level, yaitu Nasional (pusat), Provinsi, dan Kabupaten / Kota. Setiap wilayah Pemerintahan memiliki hak untuk mengatur dan mengelola anggarannya sendiri. Tingkat Pemerintahan dengan otoritas yang berbeda membuat masingmasing tingkat Pemerintahan mempunyai masalah sendiri. Hal tersebut adalah nyata sebagai sebuah bangsa yang pluralistik. ${ }^{1}$ Tidak ada yang dapat menafikan kenyataan seperti yang kita hadapi sekarang bahwa agenda Otonomi Daerah merupakan sebuah agenda nasional yang sangat penting dan telah menjadi agenda publik yang utama di tengahtengah menghadapi persoalan bangsa yang semakin komplek dan tidak jelas arahnya.

Otonomi Daerah merupakan aspek penting dalam penyelenggaraan ketatanegaraan di Indonesia. Begitu pentingnya, sehingga semua Undang-Undang Dasar (UUD) baik Undang-Undang Dasar 1945 sebelum amandemen dan setelah amandemen, Undang-Undang Dasar Repubik Indonesia Serikat (UUD RIS), Undang-Undang Dasar Sementara (UUDS) memuat prinsip otonomi Daerah. Di setiap Negara yang penyelenggaraan pemerintahannya membagi- bagi dalam daerah otonom, memiliki sejarah kebangsaannya yang berbeda-beda. Bagi negara Indonesia penyelenggaraan otonomi daerah tidak sekedar adanya penyerahan kewenangan pemerintahan dari pemerintah (pusat) kepada daerah agar Pemerintahan berjalan efektif dan efisien saja. Akan tetapi mendorong keterlibatan aktif dari masyarakat untuk terlibat dalam penyelenggaraan pemerintahan. Dengan otonomi daerah akan mempercepat perwujudan kesejahteraan masyarakat. Dengan demikian, salah satu ciri penyelenggaraan otonomi daerah adalah bahwa pemerintahan diselenggarakan secara partisipatif. Aspirasi masyarakat menjadi dasar hak dan kewenangan daerah untuk mengatur dan mengelola anggaran mereka.

Undang-Undang Nomor 23 tahun 2014 tentang Pemerintahan Daerah merupakan dasar pemberlakukan otonomi daerah di Indonesia. Dalam salah satu konsiderannya disebutkan bahwa "penyelenggaraan pemerintahan daerah diarahkan untuk mempercepat terwujudnya kesejahteraan masyarakat melalui peningkatan pelayanan, pemberdayaan, dan peran serta masyarakat, serta peningkatan daya saing daerah dengan memperhatikan prinsip demokrasi, pemerataan, keadilan, dan kekhasan suatu daerah dalam sistem Negara Kesatuan Republik Indonesia".

1 Ibnu Tricahyo, Reformasi Pemilu: Menuju Pemisahan Pemilu Nasional dan Lokal, (Malang: Intrans Publishing, 2009), hlm. 12. 
Menunjuk dimensi esensial mulai tahun 1999-2002 begitu penting dan penyelenggaraan otonomi daerah di atas, menempati peran vital bagi jalannya sistem sejatinya dalam penyelenggaraan politik kenegaraan di Indonesia. Partai bukan saja pemerintahan daerah peran serta masyarakat menjadi agen demokrasi, namun juga agen sangatlah menentukan. Masyarakat daerahlah perubahan Negara. Mau tidak mau dan suka tidak yang membentuk Pemerintahan Daerah (Pemda) melalui mekanisme Pemilu untuk memilih anggota Dewan Perwakilan Rakyat Daerah (DPRD) dan Kepala Daerah secara langsung. Di sisi lain, salah satu institusi yang juga memiliki andil penting dalam penyelenggaraan Otonomi Daerah adalah Partai Politik.

Partai politik berdasarkan Undang-Undang Nomor 2 tahun 2008 tentang Partai Politik dimaknai sebagai "organisasi yang bersifat nasional dan dibentuk oleh warga Negara Indonesia secara sukarela atas dasar kesamaan kehendak dan cita-cita untuk memperjuangkan dan membela kepentingan politik anggota, masyarakat, bangsa dan Negara, serta memilihara keutuhan Negara kesatuan Republik Indonesia berdasarkan Pancasila dan Undang-Undang dasar Negara republik Indonesia tahun $1945 \%{ }^{2}$ Peran partai politik sejak pemilu 1999 dan pasca suka di pundak partai politiklah sebagian urusan kenegaraan diserahkan melalui otoritas yang diberikan oleh Undang-Undang 1945 pasca amandemen. ${ }^{3}$

Keberadaan partai politik dalam penyelenggaran Pemerintahan berada pada titik sentral, yaitu menempatkan orang terbaik dalam proses pemilihan atau suksesi kepemimpinan mulai tingkat pusat hingga Daerah. Di dalam Undang-Undang Nomor 2 tahun 2008 tentang partai politik, secara khusus partai politik memiliki beberapa tujuan, yaitu:

a. Meningkatkan partisipasi politik anggota dan masyarakat dalam rangka penyelenggaraan aktifitas dan agenda politik dan Pemerintahan.

b. Memperjuangkan cita-cita partai dalam kehidupan bermasyarakat, berbangsa dan bernegara.

c. Membangun etika dan budaya politik.

Selain itu, Partai politik juga memiliki amandemen UUD 1945 selama 4 (empat) kali

2 Undang-Undang No 2 tahun 2011 tentang Partai Politik, Lembaran Negara Republik Indonesia Tahun 2008 Nomo 2, Tambahan Lembaran Negara Republik Indonesia Nomor 4801) sebagaimana telah diubah dengan UndangUndang Nomor 2 tahun 2011 tentang Perubahan atas Undang-Undang Nomo 2 Tahun 2008 tentang Partai politik (lembaran Negara Republik Indonesia tahun 2011 Nomor 8, Tambahan Lembaran Negara Republik Indonesia Nomor 5189).

3 Agus Riwanto, Hukum Partai Poltik dan Hukum Pemilu di Indonesia, (Yogjakarta: Thafa media, 2016), hlm, 324. 
a. Pendidikan politik terhadap anggota dan partai yang sama di tingkat nasional. masyarakat luas agar supaya terbentuk Pelembagaan itu dapat dilihat dari formulasi warga Indonesia yang sadar terhadap hak dan kewajibannya.

b. Menciptakan suasana dan kondisi yang kondusif bagi persatuan dan kesatuan bangsa Indonesia.

c. Penyerap, penghimpun, penyatu dan penyalur aspirasi politik rakyat untuk merumuskan, menyusun, dan menetapkan kebijakan negara.

d. Partisipasi politik warga negara Indonesia

e. Rekruitmen politik dalam pengisian jabatan politik melalui mekanisme dan tata cara demokrasi dengan menunjukan dan memperhatikan kesetaraan dan keadilan gender.

Sayangnya, sebagai organisasi yang bersifat nasional, partai politik dirasa telah gagal dalam menjalankan fungsi dan perannya. Keberadaan Partai Politik yang hanya bersifat nasional dengan struktur yang berpucuk di pusat kerap kali membuat orientasi partai mengabaikan kepentingan lokal. Pengabaian itu dikarenakan pelembagaan partai politik selama ini dimaknai sebagai hubungan strukturalisasi semata. Pola ini memposisikan politisi partai politik di daerah sebagai sub ordinat politisi mekanisme pemberhentian pengurus partai tingkat daerah yang dilakukan oleh struktur partai politik yang lebih tinggi dan berpucuk di pusat. Ketika proses intervensi oleh struktur partai di tingkat pusat itu mereduksi keinginan dan aspirasi masyarakat daerah melalui struktur partai politik di daerah, maka pada titik itulah telah terjadi penggerusan terhadap otonomi politik. ${ }^{4}$

Selain itu, partai politik juga terjebak dalam romantisme kekuasaan semata. Seluruh keputusan strategis partai menjadi domain dari pimpinan pusat partai politik, terutama terkait dengan pengisian jabatan politik dari tingkat pusat hingga daerah. Kewenangan yang begitu besar inilah yang sangat berpotensi dimonopoli oleh kepentingan pimpinan partai politik nasional. Dampaknya berakibat pada politik transaksional antara calon dengan pimpinan partai politik yang tidak diukur dari kualitas calon, melainkan diukur dari kepentingan pragmatisme kekuasaan salah satunya yaitu melalui mahar politik. Di dalam Statuta (AD/ART) salah satu partai politik disebutkan bahwa ketua umum sebagai sentral kekuatan politik partai yang berwenang, bertugas, bertanggungjawab dan bertindak baik ke dalam

4 M. Rifqinizamy Karsayuda, Partai Politik Lokal Untuk Indonesia: Kajian Yuridis Ketatanegaraan Pembentukan Partai Politik Lokal di Indonesia Sebagai Negara Kesatuan, (Jakarta: PT Raja Grafindo Persada, 2015), hlm. 10. 
maupun keluar atas nama partai dan eksistensi partai, program dan kinerja partai. ${ }^{5}$

Komisi Pemberantas Korupsi (KPK) dari tahun 2004-2018 mencatat terdapat korupsi yang berdimensi politik dengan jumlah 368 orang yang terdiri dari anggota Dewan Perwakilan Rakyat (DPR) dan DPRD sebanyak 247 orang, Gubernur sebanyak 20 orang, Walikota/Bupati dan Wakil sebanyak 101 orang. $^{6}$ Jumlah ini terbilang sangat fantastis, dimana Partai Politik sesungguhnya juga bertanggung jawab dalam menseleksi dan memastikan para kadernya agar tidak melakukan Korupsi ketika telah menjabat sebagai DPR, DPRD, Gubernur/Wakil Gubernur, Bupati/ Wakil Bupati dan Walikota/ Wakil Walikota.

Hasil penelitian LIPI dan KPK menunjukan sekurang-kurangnya terdapat beberapa faktor yang menjadi penyebab persoalan integritas partai, yaitu: Pertama, akibat tidak adanya standar etik partai politik dan politisi. Profesi politisi sebenarnya adalah profesi mulia yang menyalurkan aspirasi masyarakat, mendukung agregasi politik warga dan melayani masyarakat dalam proses kehidupan berbangsa dan bernegara. Namun, faktanya masih mengungkap sejumlah fakta tentang korupsi yang sering terjadi pada politisi partai. Terdapat indikasi bahwa partai politik hanya dijadikan sebagai kendaraan politik bagi sebagian politisi untuk memperoleh pekerjaan dan dapat menghimpun harta kekayaan. Oleh karena itu penting memperkenalkan standar etika yang lebih inklusif untuk melayani partai sebagai panduan untuk pemeliharaan integritas politik dan standar internal untuk mengurangi risiko korupsi politik yang mungkin dilakukan oleh politisi partai. Kedua. Rekrutmen dan kaderisasi yang berjalan secara tradisional, perekrutan politik tertutup, eksklusif dan Nepotis. Salah satu faktor di balik produk rekrutmen politik sejauh ini belum menghasilkan politisi yang jujur adalah kurangnya sistem rekrutmen politik yang terbuka, demokratis, dan akuntabel di antara partai-partai politik di Indonesia. Beberapa partai politik mengambil sumber mereka untuk perekrutan politik dari lingkungan keluarga dan kerabat elit politik partai politik itu sendiri. Ketiga, Pendanaan partai politik yang tidak tranparan dan akuntabel. $^{7}$

Persoalan integritas partai politik sesungguhnya memiliki keterhubungan dengan keberhasilan penyelenggaraan Otonomi Daerah.

5 Pasal 28 Anggaran Dasar dan Anggaran Rumat Tangga Partai Demokrasi Indonesia Perjuangan (PDI-P) tahun 2015-2020.

6 https://acch.kpk.go.id/id/statistik/tindak-pidana-korupsi/tpk-berdasarkanprofesijabatan diakses pada tanggal 18 Januari 2019.

7 Syamsuddin Haris dkk, Kertas Posisi (Position Paper) Sistem Integritas partai Politik, (Jakarta: Diteritkan oleh KPK dan LIPI, 2017), hlm. 3. 
Hubungan antara partai politik dan otonomi Daerah seperti dua sisi koin yang tidak bisa dipisahkan. Tujuan Otonomi Daerah akan dapat segera terwujud jika peran dan fungsi partai politik berjalan secara optimal. Sayangnya hal tersebut belum terjadi. Tidak berjalannya partai politik dalam memperkuat penyelengaraan otonomi Daerah dapat dimaknai bahwa perlu untuk mengatur sistem kepartaian baru di Indonesia. Salah satunya adalah dengan melakukan pemisahan antara partai politik nasional dengan partai politik lokal yang ada di daerah. Pemisahan tersebut berlaku tidak hanya pada satu daerah saja akan tetapi berlalu untuk seluruh daerah di Indonesia. Artiya dengan adanya kebijakan otonomi daerah maka harus dibarengi dengan adanya otonomi politik melalui partai politik lokal.

Keberadaan partai politik lokal di Indonesia bukanlah hal baru. Partai politik lokal di Aceh menjadi penanda bahwa partai politik lokal dapat eksis dalam mengawal penyelenggaraan otonomi khusus di Pemerintahan Aceh. Kelahiran Partai Politik Lokal di Aceh didasarkan pada perjanjian perdamaian antara Pemerintah Republik Indonesia dan Gerakan Aceh Merdeka
(GAM) melalui perjanjian Helsinki (MoU Hensinki). MoU Helsinki memberikan mandat untuk merumuskan peraturan perundangundangan baru bagi Pemerintahan Aceh. ${ }^{8}$

Pada Angka 1.1.1 MoU mengamanatkan, Undang-Undang baru tentang Pemerintahan Aceh harus secepatnya disahkan dan diimplementasikan, atau setidaknya paling lambat pada 31 maret 2006. Angka 1.2 tentang partisipasi politik menyatakan bahwa Pemerintah Indonesia harus memfasilitasi pembentukan partai-partai lokal di Aceh, dalam lingkup ketentuan dan aturan di tingkat nasional. ${ }^{9}$

Secara historis keistimewaan Aceh diatur berdasarkan Keputusan Perdana Menteri Nomor 1/Misi/1959 dan oleh Undang-Undang Nomor 18 Tahun 1965 tentang Pokok-Pokok Pemerintahan Daerah. Keistimewaan Aceh efektif dimulai pasca Orde Baru dengan dikeluarkannya UndangUndang Nomor 44 Tahun 1999 tentang Penyelenggaraan Keistimewaan Propinsi Daerah istimewa Aceh. Dalam Undang-Undang ini Islam menjadi ikon pemberlakuan desentralisasi asimetris bagi Aceh. Undang Undang ini mengatur penyelenggaraan kehidupan beragama diwujudkan dalam bentuk pelaksanaan Syariah Islam bagi pemeluknya dalam masyarakat. Selanjutnya Terdapat 3 (tiga) regulasi penting

8 Murizal Hamzah, Aceh: Peran Demokrasi Bagi Perdamain dan Rekonstruksi, Cetakan 2, (Yogjakarta: PCD Press Indonesia (PolGov), 2010), hlm. 406.

9 Nota Kesepahaman antara Pemerintah Republik Indonesia dan Gerakan Aceh Merdeka (dibaca: MoU Helsinki) diakses pada tanggal 15 Januari 2019. 
yang secara evolutif membentuk desain Pemerintahan Aceh yang asimetris (otonomi khusus) dalam relasinya dengan Pemerintah Pusat. ${ }^{10}$ Yaitu:

a. Undang-Undang Nomor 18 tahun 2001 tentang Otonomi Khusus Daerah Istimewa Aceh sebagai Proponsi Nanggroe Aceh Darussalam. Pengaturan otonomi khusus dalam hal keuangan (dana perimbangan) diatur lebih detail dalam Peraturan Pemerintah (PP).

b. Undang-Undang Nomor 32 tahun 2004 tentang Pemerintahan Daerah". Penguatan definisi otonomi khusus yang lebih jelas dalam Pemerintah Daerah. Saat ini, Undang-Undang tersebut telah diganti dengan Undang-Undang Nomor 23 tahun 2014 tentang Pemerintahan Daerah". Undang-Undang ini mengatur mengenai dana penyelanggaraan otonomi khusus.

c. Undang-Undang Nomor 11 tahun 2006 tentang Pemerintahan Aceh. Mengatur secara lengkap aturan kekhususan otonomi di Pemerintah Aceh, mengatur tentang kewenangan, kelembagaan dan keuangan.

Undang-Undang Nomor 11 tahun 2006 tentang Pemerintahan Aceh dalam Pasal 7 ayat (1), memberikan kewenangan kepada Pemerintahan Aceh dan Kabupaten/Kota mengatur dan mengelola urusan Pemerintahan di semua area publik kecuali urusan pemerintah pusat. Kewenangan pemerintah pusat meliputi, urusan luar negeri, pertahanan, keamanan, pengadilan, moneter dan fiskal dan urusan tertentu dalam bidang agama. Sejatinya Konsep Otonomi Khusus tidak jauh berbeda dengan Otonomi Daerah. Hanya saja ada sejumlah tambahan kewenangan lain yang diberikan pemerintah pusat kepada daerah dengan otonomi Khusus. Misalnya terkait dengan pengelolaan keuangan, pembentukan kelembagaan salah satunya adalah pembentukan partai poltik lokal. Selain itu, berkaitan dengan eksistensi partai lokal juga diatur dalam Pasal 1 angka 14 UndangUndang Nomor 11 tahun 2006 tentang Pemerintahan Aceh yang menyebutkan bahwa partai politik lokal adalah organisasi politik yang dibentuk oleh sekelompok warga Negara Indonesia yang berdomisili di Aceh secara sukarela atas dasar persamaan kehendak dan citacita untuk memperjuangkan kepentingan anggota, masyarakat, bangsa dan Negara melalui pemilihan anggota DPRA/DPRK, Gubernur/ Wakil Gubernur, Bupati/Wakil Bupati, dan Walikota/Wakil Walikota. Pendirian/ Pembentukan partai politik lokal di Aceh juga

10 Loporan akhir, “Desentralisasi Asimetris yang menyejahterakan Aceh dan Papua” oleh JPP FISIPOL UGM dan TIFA, 2012, hlm. 76. 
diatur melalui Peraturan Pemerintah Nomor 20 tahun 2007 tentang partai politik lokal di Aceh.

Oleh karena itu, penting melihat sejauhmana peran partai politik lokal di Aceh dalam penyelenggaraan otonomi khusus. Hal ini dilakukan sebagai pembanding dan tolak ukur yang komperhensif agar dapat dijadikan dasar pertimbangan pemberlakukan partai politik lokal di Daerah lain. Peran partai politik lokal di Aceh dalam penyelenggaraan otonomi khusus akan dilihat melalui peran institusi politik Dewan Perwakilan Rakyat Aceh (DPRA), sebagaimana telah diketahui bahwa anggota DPRA berasal dari partai politik dan keterwakilan partai politik di dalam DPRA termanifestasikan melalui Fraksi. Latar belakang keberadaan partai politik lokal di Aceh juga dikaji, apakah kelahiran partai politik lokal bertujuan untuk mendukung penyelenggaraan otonomi khusus di Aceh atau ada tujuan lain dibaliknya sehingga dapat ditarik benang merah antara keduanya.

Berdasarkan latar belakang di atas, rumusan masalah dalam tulisan ini adalah, Pertama: Bagaimana Peran Partai Politik Lokal Dalam Penyelenggaraan Otonomi Khusus? Kedua, Apakah Partai Politik Lokal Telah Berperan dalam Penyelenggaraan Otonomi Khusus? Sebagaimana dijelaskan dalam latar belakang permasalahan, penelitian ini dilakukan dengan tujuan, Pertama, Mendeskripsikan peran-peran yang dimiliki oleh partai politik lokal Aceh dalam penyelenggaraan Otonomi Khusus. Terutama berkaitan dengan peran partai politik lokal melalui Fraksi partai politik lokal yang berada di Dewan Perwakilan Rakyat Aceh (DPRA), dan Kedua, Menganalisis peran yang telah dilakukan oleh partai politik lokal di Aceh dalam penyelenggaraan Otonomi Khusus.

Penelitian yang dipergunakan dalam penelitian ini adalah jenis penelitian hukum empiris yaitu penelitian yang mengkaji hukum tidak saja sebagai norma yang pasif tetapi hukum dan peraturan dalam implementasinya, atau lazim disebut penelitian non doktrinal atau Empiris. Hal ini didasarkan pada pemikiran bahwa penelitian ini mengakaji terhadap peran dari partai politik lokal dalam penyelenggaraan otonomi khusus di Aceh.

Penelitian ini dimulai dengan melakukan penelusuran terhadap dokumen-dokumen hasil penyelenggaraan otonomi khusus, terutama berkaitan dengan dokumen yang berasal dari fraksi partai politik lokal dan keseluruhan regulasi-regulasi yang memiliki keterkaitan dengan permasalah yang diteliti, yang kemudian penulis melakukan pengamatan melalui dokumen-dokumen yang ada secara mendalam yang berkaitan dengan apakah partai politik lokal 
telah berperan dalam penyelenggaraan otonomi Khusus. Untuk mengukur peran partai politik dilihat dari beberapa hal. Pertama, Hasil dari pemilu legislatif di Aceh tahun 2014. Yaitu dengan melihat sejauhmana tingkat keterpilihan partai politik lokal dalam penyelenggaraan Pemilihan legislatif. Kedua, Sejauhmana Partai Politik lokal melalui fraksinya yang berada di DPRA mampu menjalankan peran dan fungsinya secara Optimal.

\section{HASIL DAN PEMBAHASAN}

Peran Fraksi Partai Politik Lokal dan Dewan Perwakilan Rakyat Aceh (DPRA) dalam Penyelenggaraan Otonomi Khusus di Provinsi Aceh

Peran partai Politik lokal di Aceh dapat diukur berdasarkan fungsi partai politik lokal yang berada di Dewan Perwakilan Rakyat Aceh (DPRA). Melalui fraksi yang berada di DPRA partai politik lokal dapat berperan dalam penyelanggaraan otonomi khusus di Aceh. Kewenangan fraksi sepenuhnya diberikan oleh Peraturan Tata Tertib Dewan Perwakilan Rakyat Aceh, tujuan di bentuknya fraksi adalah untuk mengoptimakan dan mengefektifkan pelaksanaan tugas, wewenanag, serta hak dan kewajiban DPRA. Tujuan tersebut dinilai sebagai tujuan yang das sollen, sebab dalam kenyataanya fraksi justru menjadi saluran tunggal untuk memaksakan kepentingan politik partai kepada anggota Dewan Perwakilan Rakyat Aceh.

Meski bukan alat kelengkapan Dewan Perwakilan Rakyat Aceh yang mempunyai penjabaran tugas tertentu, dalam kenyataanya fraksi mempunyai peran yang signifikan. Sebab, dalam proses DPRA fraksi tidak mungkin di tinggalkan. Penyusunan Rancangan Peraturan Daerah/Qanun, pelaksanaan hak DPR yaitu hak interplasi, hak menyatakan pendapat, dan hak angket, serta dalam setiap pengambilan keputusan ada keterlibatan fraksi. Di parlemen Jerman (Bundestag), anggota fraksi harus merupakan asosiasi anggota DPR dari partai politik yang sama. Meskipun dibeberapa sistem parlemen dengan banyak partai, para anggotanya tidak terikat secara hukum pada fraksi karena mandat tersebut bersifat pribadi, para anggota sering hanya melalui partai untuk mendapatkan kursi Dewan Perwakilan Rakyat dan menjalankan mandat mereka secara efektif. ${ }^{11}$

Selama ini terlihat jelas besarnya peran fraksi dalam proses pelaksanaan fungsi, tugas, dan hak DPRA, bahkan menentukan dalam pengambilan keputusan. Konsekuensinya, kinerja Dewan Perwakilan Rakyat Aceh (DPRA) dipengaruhi oleh fraksi. Dari persepektif anggota dapat

11 Yuswanto, Kedudukan Fraksi di Dewan Perwakilan Rakyat Berdasarkan Undang-Undnag Nomor 17 Tahun 2014 tentang MPR, DPR, DPD, dan DPRD, JOM Fakultas Hukum, Vol. III, Nomor 2, Tahun 2016. 
diperkirakan, pendirian maupun pendapat seorang anggota DPR dalam pelaksanaan fungsi, tugas, dan hak DPR harus searah dengan pendirian fraksi. Fraksi adalah pengelompokan anggota DPRA yang mencerminkan konfigurasi partai politik dan partai politik lokal peserta pemilihan umum.

${ }^{12}$ Fraksi bertugas:

1. Menentukan dan mengatur segala sesuatu yang menyangkut urusan fraksi masingmasing;

2. Meningkatkan kualitas, kemampuan, disiplin, daya guna dan hasil guna para anggotanya dalam melaksanakan tugas yang tercermin dalam setiap kegiatan DPRA;

3. Menyampaikan saran dan pendapat akhir pada setiap pembahasan dalam Rapat Paripurna yang melahirkan Keputusan DPRA;

4. Menerima dan wajib memperjuangkan aspirasi masyarakat; dan

5. Mensosialisasikan informasi-informasi kepada anggotanya.

6. Fraksi-fraksi DPRA baik diminta atau tidak, dapat memberikan pertimbangan kepada Pimpinan DPRA mengenai hal- hal yang dianggap perlu berkenaan dengan bidang tugas DPRA.

Berdasarkan Undang-Undang Nomor 11 tahun 2006 tentang Pemerintahan Aceh, Dewan Perwakilan Rakyat Daerah Aceh (DPRA) adalah unsur penyelenggara Pemerintahan Daerah Aceh yang anggotanya dipilih melalui pemilihan umum. DPRA mempunyai fungsi legislasi, anggaran dan pengawasan terhadap penyelenggaraan Pemerintahan (otonomi khusus).

Tingkat Partisipasi terhadap Pemilihan Partai Politik Lokal Aceh dalam Penyelenggaraan Pemilihan Dewan Perwakilan Rakyat Aceh Tahun 2014

Secara eksplisit, Robert Dahl (1971) menegaskan bahwa demokrasi melibatkan dua varibel, yaitu kontestasi dan partisipasi yang sangat menentukan bagi proses perkembangan demokrasi. Dalam implementasi demokrasi prosedural elektoral yang mengagendakan penyelenggaraan pemilu secara regular, memang partisipasi politik rakyat merupakan faktor dan indikator dominan bagi keberhasilan demokrasi. ${ }^{13}$

Dalam Negara-Negara domokratis umumnya dianggap bahwa lebih banyak partisipasi masyarakat lebih baik. Dalam alam pikiran ini tingginya tingkat partisipasi menunjukan bahwa

12 Peraturan DPRA No. 1 Tahun 2016 tentang Tata Tertib DPRA.

13 In'amul Mushoffa dkk, Konsep Memperdalam Demokrasi: Dari Procedural ke Substantif, Menuju Representasi Politik yang Berkualitas, (Malang: Intrans Publishing, 2016), Hlm. 8-9. 
warga Negara mengikuti dan memahami masalah politik dan ingin melibatkan diri dalam politik. Sebaliknya, tingkat partispasi yang rendah pada umumnya dianggap sebagai tanda yang kurang baik, karena diartikan bahwa banyak warga Negara tidak menaruh perhatian terhadap masalah kenegaraan. Partai politik dalam hal ini memiliki peran yang sangat startegis untuk mendorong dan meningkatkan partisipasi masyarakat, terutama dalam penyelenggaraan demokrasi elektoral. Baik itu pemilihan presiden dan wakil presiden, pemilihan DPR dan DPRD Provinsi/Kota/Kabupaten, pemilihan Kepala Daerah Provinsi/Kota/ Kabupaten.

Pada tahun 2014, data dari Komisi Independen Pemilihan (KIP) menunjukan partisipasi pemilih Pemilu Legislatif di Provinsi Aceh mencapai 77.58\%, jumlah ini melampaui target sebesar 75\%. Jumlah pemilih tetap Pemilu Legislatif di Aceh sebanyak 3.370 .844 orang, sedangkan masyarakat yang menggunakan hak pilihnya tercatat 2.615.264 orang. Tingkat partisipasi ini juga meningkat dibandingkan pemilihan gubernur pada tahun 2012. ${ }^{14}$

Peserta Pemilu dan pemilihan DPRA terdiri dari partai Nasional dan Partai Lokal dengan jumlah seluruhnya sebanyak 15
Partai. Berikut Partai Nasional: Nasional Demokrat (NASDEM), Partai Kebangkitan Bangsa (PKB), Partai Kesejahteraan Sosial (PKS), Partai Demokrasi Indonesia Perjuangan (PDIP), Golongan Karya (GOLKAR), Gerakan Indonesia Raya (GERINDRA), Demokrat, Partai Amanat Nasional (PAN), Partai Persatuan Pembangunan (PPP), Hati Nurani Rakyat (HANURA), Partai Bulan Bintang (PBB), Partai Keadilan dan Persatuan Indonesia (PKPI). Partai Lokal: Partai Aceh (PA), Partai Nasional Aceh (PNA), Partai Damai Aceh (PDA).

Data di bawah menunjukan bahwa Partai Aceh mendapatkan jumlah suara sebesar 35.34\%, Partai Nasional Aceh (PNA) sebesar 4.73\%, Partai Daerah Aceh (PDA) sebesar 3.03\% dan jika digabungkan memperoleh total suara sebesar 43.10\%. Data tersebut berasal dari penjumlahan suara yang berada di 10 (sepuluh) daerah pemilihan (Dapil). Meskipun tidak semua partai politik lokal Aceh mendapat suara signifikan, namun Partai Aceh mendapatkan suara yang sangat besar dibandingkan dengan Partai Nasional.

14 https://Aceh.antaranews.com/berita/11161/partisipasi-pemilih-di-Aceh-capai-7758-persen diakses pada tanggal 16 April 2019, pukul 13.33 WIB. 


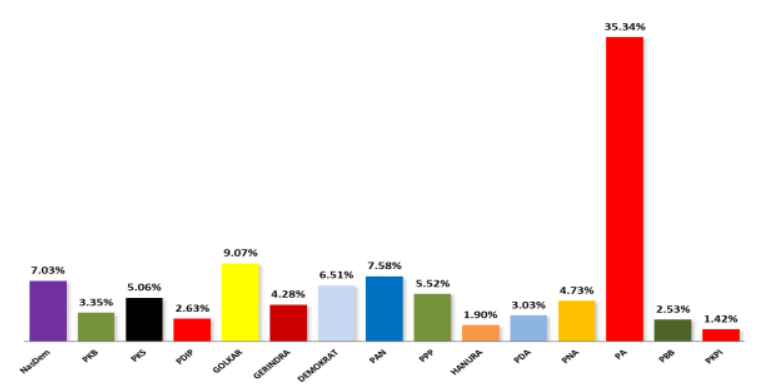

Grafik 1. Prosentase Perolehan Partai Politik dalam Penyelenggaraan Pemilihan DPRA tahun 2014 ${ }^{15}$

Besarnya jumlah suara yang didapatkan oleh Partai Aceh juga berkorelasi dengan jumlah kursi yang diperoleh. Partai Aceh mendapatkan jumlah kursi sebesar 29 Kursi dari 81 total kursi di DPRA, Partai Nasional Aceh mendapatkan 3 kursi dan Partai Daerah Aceh mendapatka 1 kursi. Disisi lain, terdapat partai nasional yang justru tidak mendapatkan kursi satupun, yaitu PDIP dan Partai Hanura. Partai Nasional yang tidak mendapatkan kursi disebabkan karena jumlah suara yang ada di dapil tidak memunuhi atau mencukupi setelah dibagi menggunakan mekanisme perhitungan angka Bilangan Pembagi Pemilihan (BPP).

Peran Pembentukan Peraturan Daerah/Qanun (Legislasi) oleh Fraksi Partai Politik Lokal
Peran Legislasi dapat dilihat dari sejauh mana jumlah Qanun yang dapat diselesaikan oleh DPRA. Artinya dapat diperbandingkan antara jumlah rencana legislasi dengan realisasi legislasi. Pada tahun 2017 rencana legislasi yang berasal dari inisiatif DPRA sebanyak 3 rencana dan 1 realisasi. Sedangkan pada tahun 2018 rencana legislasi sebanyak 5 rencana dan realisasinya sebanyak 4. Hal itu menunjukan terjadi peningkatan jumlah realisasi pada tahun 2018 dibandingkan dengan tahun 2017. Tidak terealisasinya 2 dari 3 Rancangan Qanun Aceh yang berasal dari insiatif DPRA pada tahun 2017 disebabkan karena ${ }^{16}$ :

a. Rancangan Qanun Aceh tentang Perlindungan lahan Pangan Berkelanjutan, masih dalam tahap penyiapan drfat sehingga belum bisa diproses ke tahapan selanjutnya

b. Rancangan Qanun Aceh tentang Himne Aceh, pada tahun 2017 masih dalam proses pelaksanaan kegiatan sayembara Himne Aceh untuk mendapatkan pemenang dan penyiapan draft Rancangan Qanun serta naskah akademik. Pada tahun 2018 baru dapat dilaksanakan pembahasan draft rancangan Qanun.

Sedangkan tidak teralisasinya 1 (satu) Rancangan Qanun Aceh pada tahun 2018 yang berasal dari iniatif DPRA disebabkan karena

15 Data di diambil dari Komisi Independen Pemilu (KIP) Propvinsi Aceh.

16 Data target dan Realisasi Qanun Aceh yang diperoleh melalui permohonan Informasi kepada PPID Aceh. 
Rancangan Qanun Aceh tentang Perubahan Qanun Aceh Nomor 19 tahun 2013 tentang Rencana Tata Ruang Wilayah (RTRW) Aceh, harus ada peninjauan kembali RTRW Aceh oleh Pemerintah Aceh sebelum dilakukan perubahan RTRW tersebut, sesuai dengan amanah Peraturan Menteri Agraria dan Tata Ruang Nomor 6 tahun 2017 tentang Tata cara peninjauan kembali Rencana Tata Ruang Wilayah. Namun Pemerintah Aceh belum melakukan peninjauan kembali RTRW Aceh sesuai dengan Peraturan Menteri dimaksud. Tahapan peninjauan kembali dilakukan paling lama 1 (satu) tahun terhitung sejak ditetapkannya surat keputusan penetapan pelaksanaan peninjauan kembali RTRW.

Masing-masing pengusul Rancangan Qanun Aceh yang berasal dari inisiatif DPRA bukanlah berasal dari Fraksi, melainkan berasal dari Alat Kelengkapan DPRA, mulai dari Badan Legislasi, Panitia Khusus, Komisi I, II, IV, V dan VI. Pimpinan Badan Legislasi, Badan Musyawarah, Badan Anggaran, Komisi I, Komisi II, Komisi IV dan Panita Khusus semuanya diketuai oleh Fraksi Partai Aceh. Sedangkan Komisi V diketuai oleh Fraksi PAN dan Komisi VI diketua oleh Fraksi Nasdem. Hal ini sekali lagi menjukan bahwa Fraksi Partai Politik lokal sangat mendominasi dibandingkan dengan Fraksi Partai Politik Nasional.

Selain itu, berdasarkan uraian pendapat akhir fraksi partai politik lokal terhadap rancangan Qanun, telah terlihat peran partai politik lokal dalam menjalankan fungsi legislasi yang termanifestasikan melalui pendapat akhir fraksi. Secara khusus Fraksi Partai Aceh telah menyampaikan sejumlah caatatan dan pandangan terhadap Rancangan Qanun yang berkaitan dengan penyelenggaraan otonomi khusus secara baik dan kritis dibandingkan dengan 2 (dua) fraksi partai politik nasional.

Peran Pengawasan (Controling) Fraksi Partai

\section{Politik Lokal}

Pada tahun 2018 DPRA menggunakan Hak Interpelasi kepada Gubernur Aceh. ${ }^{17}$ Dan sebagian besar pengusul berasal dari anggota Partai Politik Lokal, yaitu Partai Aceh. Berikut proses berjalannya Hak Interpelasi DPRA terhadap Gubernur Aceh:

1. Surat dari pengusul Hak Interpelasi terhadap Gubernur Aceh bernomor istimewa tertanggal 2 Mei 2018 perihal Usulan Penggunaan Hak Interpelasi terhadap Gubernur Aceh Sdr. Irwandi Yusuf yang ditandatangani oleh 46 (empat puluh enam) Anggota DPR Aceh. 46 Anggota DPRA tersebut terdiri dari 26 Anggota dari Partai Aceh, 4 dari Partai PAN,

17 Data Hak Interpelasi DPRA terhadap gubernur Aceh yang diperoleh melalui permohonan Informasi 
3 dari Partai Gerindra, 3 dari PKS, 3 dari Partai Nasdem, 2 dari Golkar, 1 dari PDA, 1 dari PBB, 1 dari PPP dan 1 dari PKPI. Berikut sejumlah alasan penggunaan Hak Interpelasi:

a. Gubernur Aceh Sdr. Irwandi Yusuf telah melakukan pelanggaran sejumlah peraturan perundangundangan dalam kaitannya dengan penerbitan Peraturan gubernur (PERGUB) Nomor 9 Tahun 2018 tentang Anggaran Pendapatan dan Belanja Aceh (APBA) Tahun Anggaran 2018.

b. Gubernur Aceh Sdr. Irwandi Yusuf telah melakukan pelanggaran peraturan perundang-undangan dalam kaitan dengan penerbitan Peraturan Gubernur (PERGUB) Nomor 5 tahun 2018 tentang Pelaksanaan Hukum Acara Jinayah (pengalihan tempat pelaksanaan hukuman cambuk dari tempat terbuka untuk umum ke dalam penjara/lapas)

c. Gubernuh Aceh Sdr. Irwandi Yusuf diduga telah menerima uang suap sebesar Rp. 14.069.375.000, - (empat belas milyar enam puluh sembilan juta tiga ratus tujuh puluh lima ribu rupiah),- sebagaimana disebutkan pada surat dakwaan Jaksa KPK dalam perkara terdakwa Ruslan Abdul gani (mantan Kepala BPKS Sabang).

d. Gubernur Aceh Sdr. Irwandi Yusuf disamping telah melanggar hukum juga telah melakukan pelanggaran sumpah jabatan sebagai Gubernur Aceh terutama kewajiban untuk menjalankan Pemerintahan dengan sebaik-baiknya dan seadil-adilnya, memegang teguh UndangUndang dan peraturannya dengan seluruslurusnya serta berbakti kepada masyarakat, nusa dan bangsa.

e. Gubernur Aceh Sdr. Irwandi Yusuf disamping telah melakukan pelanggaran hukum, melanggar sumpah jabatan dan juga telah melakukan pelanggaran moral/etika, baik dalam pelaksanaan tugas maupun dalam hal komunikasi dengan sesama penyelenggara Negara/ Pemerintahan juga dengan berbagai kalangan masyarakat Aceh. Sering sekali berbicara dan bersikap yang memicu perpecahan antar lembaga penyelenggara Negara/Pemerintahan dan masyarakat. Tidak menjaga dan memelihara perdamaian Aceh yang baru pulih dari konflik yang berkepanjangan di masa yang lalu.

Permohonan usulan Hak Interpelasi ini sesuai dengan ketentuan Pasal 25 ayat (1) sub a Undang-Undang nomo 111 Tahun 
2006 Tentang Pemerintahan Aceh jo.

Pasal 7, 8 dan 9 Peraturan Nomor 1

Tahun 2016 tentang tata Tertib Dewan

Perwakilan Rakyat Aceh.

2. Rapat Badan Musyawarah DPRA pada tanggal 4 Mei 2018, DPR Aceh sepakat akan menggunakan Hak Interpelasi terkait dengan dokumen Peraturan Gubernur (Pergub) Aceh Tahun 2018 dan akan diminta persetujuan dalam rapat paripurna DPRA.

3. Rapat Badan Musyawarah DPRA pada tanggal 7 Mei 2018 menetapkan kesimpulan untuk pelaksanaan rapat paripurna khusus DPRA dengan agenda yang salah satunya adalah persetujuan terhadap penggunaan Hak Interpelasi DPRA pada hari rabu tanggal 9 Mei 2018 pukul 20.30 WIB.

4. Pada Rapat Paripurna Khusus DPRA tanggal 9 Mei 2018, DPRA memberikan persetujuan terhadap penggunaan Hak Interpelasi DPRA yang ditetapkan dengan Keputusan DPRA nomor 16/DPRA/2018 tentang persetujuan penggunaan Hak Interpelasi DPRA terhadap Gubernur Aceh.

5. DPRA Menyurati Gubernur Aceh pada tanggal 21 Mei 2018 dengan nomor surat 161/1251 perihal penyampaian Surat Keputusan DPRA tentang persetujuan
Penggunaan Hak Interpelasi DPRA terhadap gubernur Aceh.

6. Pada hari Rabu tanggal 23 Mei 2018 dilaksanakan rapat Badan Musyawarah DPRA yang menetapkan pelaksanaan rapat Paripurna Istimewa DPRA dalam rangka mendengarkan jawaban Gubernur Aceh terhadap Hak Interpelasi DPRA pada hari kamis tanggal 4 Juni 2018 pukul 09.00 WIB.

7. Gubernur Aceh dengan surat nomor 162/18045 tanggal 31 Mei 2018 yang ditujukan kepada ketua DPRA meminta agar dapat menjadwalkan kembali Rapat Paripurna Istimewa DPRA yang sedianya akan dilaksanakan pada hari senin tanggal 4 Juni 2018 karena gubernur Aceh masih melakukan ibadah Umrah.

8. Rapat Paripurna Istimewa DPRA pada hari senin tanggal 4 Juni 2018 dengan agenda mendengarkan jawaban Gubernur Aceh terhadap Hak Interpelasi DPRA tidak dihadiri oleh Gubernur Aceh dan akan dijadwalkan paripurna kedua dalam rapat Badan Musyawarah DPRA.

9. Pada hari senin malam sampai selasa dini hari tanggal 4-5 Juni 2018 dilaksanakan rapat badan Musyawarah DPRA dengan menetapkan pelaksanaan rapat Paripurna Istimewa DPRA mendengarkan Jawaban Gubernur Aceh terhadap Hak Interpelasi 
DPRA pada hari Kamis tanggal 28 Juni 2018 pukul 09.00 WIB.

10. Paripurna Istimewa DPRA dengan agenda mendengar jawaban Gubernur Aceh pada hari kamis tanggal 28 Juni 2018 pukul 10.00 WIB, Pimpinan dan anggota DPRA menolak terhadap Jawaban/Penjelasan Gubernur Aceh atas Hak Interpelasi dan akan diagendakan kembali pada hari senin tanggal 2 Juli 2018 pukul 09.00 WIB.

11. Rapat Badan Musyawarah DPR Aceh pada hari Kamis tanggal 28 juni 2018 menetapkan Lanjutan Parpurna Istimewa DPR Aceh dengan agenda mendengar Jawaban Gubernur Aceh dilaksaakan pada haru Senin tanggal 2 Juli 2018 pukul 09.00 WIB.

12. Pada hari Senin tanggal 2 Juli 2018 dilaksanakan rapat Paripurna Istimewa DPR Aceh dengan agenda Mendengar Jawaban Gubernur Aceh terhadap Hak Interpelasi DPR Aceh dan dalam paripurna dimaksud Pimpinan dan Anggota DPR Aceh menolak sluruh jawaban penjelasan Gubernur Aceh atas Hak Interpelasi yang diajukan oleh DPR Aceh yang ditetapkan dengan keputusan DPR Aceh Nomor 19/DPRA/2018 tanggal 2 Juli 2018.

Dari uraian proses pelaksanaan Hak Interpelasi di atas dapat disimpulkan bahwa
Fraksi Partai Politik lokal lebih mendominasi dari pada Fraksi Partai Politik Nasional. Hal tersebut dapat dilihat dari jumlah perwakilan Fraksi Partai Aceh yang lebih banyak melakukan interupsi untuk mengkonfrontasi jawaban dari Gubernur terhadap Hak Interpelasi DPRA.

Peran Anggaran (Budget) Fraksi Partai Poltik

\section{Lokal}

Berdasarkan undang-undang, APBD dibuat pihak eksekutif, dibahas bersama DPRD dan disahkan DPRD. Artinya APBD yang dibuat eksekutif akan sah memiliki legitimasi jika sudah medapatkan pengesahan dari pihak DPRD. Dalam konteks ini, fungsi DPRD tidak hanya sekedar pada fungsi Budgeting semata, namun lebih penting lagi adalah bagaimana DPRD melakukan fungsi kontrol Budgeting secara maksimal. Artinya, DPRD tidak hanya membahas dan memberikan pengesahan $\mathrm{APBD}$, namun juga mengawasi realisasi berjalannya APBD dan mengawal agar program dan alokasi anggarannya bisa dilakukan sesuai dengan program yang telah ditetapkan sebelumnya. Selain itu, program dan alokasi anggarannya bisa tepat sasaran dan tidak mengalami penyimpangan dan kebocoran.

Dalam menjalankan peran budgeting Fraksi partai lokal telah memberikan catatan melalui pendapat akhir Fraksi Partai Aceh terhadap rancangan Qanun Aceh tentang Anggaran Pendapatan dan Belanja Aceh (APBA) tahun 2017 dan Perubahannya serta Rancangan Qanun 
tentang APBA tahun 2019. Terdapat beberapa hal yang menjadi usulan dan masukan yaitu, Infrastruktur, Kesehatan, Alokasi APBA dan Pengelolaan APBA, Penguatan Lembaga Wali Nanggroe, Pembangunan Mesium DR Muhammad Hasan di Tiro, Pelayanan Kesehatayan dan Premi Asuransi BPJS dari JKN KIS dan JK, Penanggulangan Bencana Alam, Kelangkaan Pupuk Subsidi, Elpiji, Solar dan Premium, Infrastruktur Jalan, Honor Guru dan Kemiskinan. ${ }^{18}$

\section{KESIMPULAN}

Peran Partai Politik Lokal Dalam Penyelenggaraan Otonomi Khusus dapat dilihat dari Peran Fraksi Partai Politik Lokal yang ada di Dewan Perwakilan Rakyat Aceh (DPRA), yaitu Peran Pembentukan Peraturan Perundang-undangan (Legislasi), Peran Pengawasan (Controling), dan Peran Anggaran (Budgeting). Selain itu, Peran Partai Politik Lokal juga dapat dilihat dari jumlah keterpilihan Partai Politik Lokal dalam pemilihan Dewan Perwakilan Rakyat Aceh (DPRA).

Melihat bahwa keberadaan partai politik lokal di Aceh relatif baru, yaitu pasca MoU Helsinki dan didasarkan pada UndangUndang Nomor 11 tahun 2006 tentang Pemerintahan Aceh maka partai politik lokal

perlu terus dikuatkan sebagai bagian penting dari Penyelenggaraan Otonomi Khusus di Aceh, terutama terhadap beberapa hal:

a. Pengelolaan Keuangan Partai Politik Lokal yang transparan dan akuntabel

b. Peningkatan kualias, kapasitas, kapabelitas dan Integritas Sumber daya manusia (SDM) atau anggota atau kader Partai Politik Lokal

c. Pengelolaan Program kegiatan Partai Politik lokal, terutama yang berkaitan dengan pendidikan politik kepada masyarakat

Partai politik lokal telah berperan dalam penyelenggaraan Otonomi Khusus di Aceh, maka hasil penelitian ini dapat dijadikan sebagai salah satu pertimbangan untuk menginisiasi Pembentukan Partai Politik Lokal di darerah lain atau di Provinsi lain.

\section{DAFTAR PUSTAKA}

\section{Peraturan Perundang-undangan}

Undang-Undang Nomor 2 tahun 2011 tentang Partai Politik

Undang-Undang Nomor 11 tahun 2006 tentang Pemerintahan Aceh

Peraturan DPRA Nomor 1 Tahun 2016 tentang tata tertib DPRA

Anggaran Dasar dan Anggaran Rumat Tangga Partai Demokrasi Indonesia Perjuangan (PDI-P) tahun 2015-2020.

\section{Buku}

18 Data Pendapat Akhir Fraksi partai Aceh terhadap Rancangan Qanun tentang APBA 2017 dan 2019 diperoleh dari permohonan informasi kepada PPID Aceh. 
Agus Riwanto, (2016), Hukum partai poltik dan hukum pemilu di Indonesia, Yogjakarta: Thafa media.

Ibnu Tricahyo, (2009), Reformasi pemilu: menuju pemisahan pemilu nasional dan lokal, Malang: Intrans Publishing.

In'amul Mushoffa dkk, (2016), Konsep Memperdalam Demokrasi: dari procedural ke substantif, menuju representasi politik yang berkualitas, Malang: Intrans Publishing.

M. Rifqinizamy Karsayuda, (2015) Partai Politik Lokal Untuk Indonesia: kajian yuridis ketataNegaraan pembentukan partai politik lokal di Indonesia sebagai Negara kesatuan, Jakarta: PT Raja Grafindo Persada.

Murizal Hamzah, (2010) Aceh: Peran Demokrasi Bagi Perdamain dan Rekonstruksi, Cetakan 2, Yogjakarta: PCD Press Indonesia (PolGov)

Syamsuddin Haris dkk, (2017), Kertas Posisi (Position Paper) Sistem Integritas partai Politik, (Jakarta: Diteritkan oleh KPK dan LIPI.

\section{Jurnal}

Yuswanto, Kedudukan Fraksi di Dewan Perwakilan Rakyat Berdasarkan Undang-Undnag Nomor 17 Tahun 2014 tentang MPR, DPR, DPD, dan DPRD, JOM

Fakultas Hukum, Vol III nomor 2, tahun 2016

\section{Internet}

https://acch.kpk.go.id/id/statistik/tindak-pidanakorupsi/tpk berdasarkanprofesijabatan diakses pada tanggal 18 Januari 2019.

https://Aceh.antaranews.com/berita/11161/partisi pasi-pemilih-di-Aceh-capai-7758-persen diakses pada tanggal 16 April 2019, pukul 13.33 WIB

Nota Kesepahaman antara Pemerintah Republik Indonesia dan Gerakan Aceh Merdeka (dibaca: MoU Helsinki) diakses pada tanggal 15 Januari 2019.

Loporan akhir, "Desentralisasi Asimetris yang menyejahterakan Aceh dan Papua" oleh JPP FISIPOL UGM dan TIFA, 2012

\section{Lainnya}

Data Hak Interpelasi DPRA terhadap gubernur Aceh yang diperoleh melalui permohonan Informasi

Data Pendapat Akhir Fraksi partai Aceh terhadap Rancangan Qanun tentang APBA 2017 dan 2019 diperoleh dari permohonan informasi kepada PPID Aceh

Data target dan Realisasi Qanun Aceh yang diperoleh melalui permohonan Informasi kepada PPID Aceh 